This PDF is a selection from a published volume from the National Bureau of Economic Research

Volume Title: Education, Skills, and Technical Change: Implications for Future US GDP Growth

Volume Authors/Editors: Charles R. Hulten and Valerie A. Ramey, editors

Volume Publisher: University of Chicago Press

Volume ISBNs: 978-0-226-56780-8 (cloth); 978-0-226-56794-5

(electronic); 0-226-56780-X (cloth)

Volume URL: http://www.nber.org/books/hult-12

Conference Date: October 16-17, 2015

Publication Date: December 2018

Chapter Title: Education and the Growth-Equity Trade-Off

Chapter Author(s): Eric A. Hanushek

Chapter URL: http://www.nber.org/chapters/c13938

Chapter pages in book: (p. $293-312$ ) 


\title{
Education and the Growth-Equity Trade-Off
}

\author{
Eric A. Hanushek
}

Considerable discussion surrounds the interrelationship of economic growth and the distribution of income. A common consideration generally underlying discussions about both growth and the character of the income distribution is the human capital of the population. But it has been unclear how human capital and, particularly, policies designed to improve human capital might affect growth-equity outcomes. The discussion here builds on recent analyses that focus on the interplay of cognitive skills with long-run growth and with individual earnings. This new focus provides a different perspective on how human capital development fits into the aggregate picture and suggests that the impact of various human capital policies is likely to be heterogeneous with some policies leading to growth-equity trade-offs and others to growth-equity complementarities.

Much of the growth-equity discussion has been motivated by examination of the Kuznets curve, which relates income levels of a country to an inverted U-shaped curve of income inequality (Kuznets 1955). Recent work in this heavily traveled area has gone in a variety of directions. Much of the related work has stayed at the aggregate level, focusing on variations across countries or the impact of various redistribution policies (e.g., Ostry, Berg, and Tsangarides 2014; Brueckner, Dabla Norris, and Gradstein 2015). Other work has gone into detail on various subparts such as the relationship between human capital and income inequality (e.g., Castelló-Climent and

Eric A. Hanushek is the Paul and Jean Hanna Senior Fellow at the Hoover Institution at Stanford University and a research associate of the National Bureau of Economic Research.

For acknowledgments, sources of research support, and disclosure of the author's material financial relationships, if any, please see http://www.nber.org/chapters/c13938.ack. 
Doménech 2008, 2014). ${ }^{1}$ Most, however, has only indirectly provided guidance on specific policy choices.

This chapter does not attempt to reconcile these different perspectives. Instead, the discussion focuses on recent research that links growth and individual incomes through the importance of cognitive skills. Historically, this linkage has not been the focus, even though both growth and income determination have been closely linked to ideas of human capital. The ubiquitous measurement of human capital by school attainment provides a biased view of the role of skills and leads to policy conclusions that are not suggested by a skills formulation and measurement focus. Not only are growth and individual incomes closely related to differential cognitive skills as measured by standardized achievement tests, but also this direct measure of human capital is closely aligned with many current policy discussions.

The next section describes basic results of empirical growth models. This is followed by conclusions about individual earnings determination. These discussions, which differ from many of the common developments, form the basis for considering the relationship between education policies and growth and equity objectives. With this background, it is possible to present illustrative schooling policies that produce growth-equity complementarities and that produce growth-equity trade-offs.

\subsection{Long-Run Growth}

Modern growth theory has investigated a variety of explanations for what fundamentally determines economic growth (Hanushek and Woessmann 2008). The focus has been different underlying models of how resources and institutions affect growth. And, in the empirical analysis there has been a broad attempt to discover how various factors from politics to geography enter into growth differences across countries. Important for the purposes of this discussion, virtually all developments - both theoretical and empiricalmaintain a key role for the skills of workers - that is, for human capital.

In the late 1980s and early 1990s, macroeconomists launched extensive efforts to explain differences in growth rates around the world. A variety of different issues have consumed much of the theoretical growth analysis that developed with the resurgence of growth analysis. At the top of the list is whether growth should be modeled in terms of the level of income or in terms of growth rates of income. The former is typically thought of as neoclassical growth models (e.g., Mankiw, Romer, and Weil 1992), while the latter is generally identified as endogenous growth models (e.g., Lucas 1988; Romer 1990).

The two different perspectives have significantly different implications for

1. For a broad review of the theoretical history and modeling of growth, human capital, and income inequality, see Galor (2011). 
the long-run growth and income of an economy. In terms of human capital, the focus of this discussion, an increase in human capital would raise the level of income but would not change the steady-state rate of growth in the neoclassical model. But, increased human capital in the endogenous growth model will lead to increases in the long-run growth rate. The theoretical distinctions have received a substantial amount of theoretical attention, although relatively little empirical work has attempted to provide evidence on the specific form (see Benhabib and Spiegel 1994; Hanushek and Woessmann 2008; Holmes 2013).

Both views can be considered in a stylized form of an empirical growth model:

$$
\text { growth }=\alpha_{1} \text { human capital }+\alpha_{2} \text { other factors }+\varepsilon \text {. }
$$

A country's growth rate is described as a function of workers' skills along with other systemic factors including economic institutions, initial levels of income, and technology. As noted, there have been distinct differences in how skills are seen as affecting the economy, but little of the broad theoretical work has focused on the measurement of relevant skills. Measurement issues are crucial to any empirical considerations of human capital and growth, yet surprisingly, human capital measurement has also received relatively little attention in the associated empirical analysis.

Owing to the ready availability of data (and to the standard labor economics perspective below), the quantity of schooling became virtually synonymous with human capital, so much so that the choice in empirical work is seldom explicitly considered. Thus, when growth modeling required a measure of human capital, measures of school attainment were seldom questioned. The early data construction of Barro and Lee (1993) provided the necessary data on school attainment supporting international growth work. ${ }^{2}$ Thus, equation (1) could be estimated by substituting school attainment, $S$, for human capital and estimating the growth relationship directly.

While using school attainment to measure human capital generally arouses little attention, this presents huge difficulties in an international setting. In comparing human capital across countries, it is impossible to believe that schools in Singapore yield, on average, the same learning per year as those in Brazil.

This formulation of the growth model also presumes schooling is the only source of human capital and skills. Yet, the very large literature on education production functions (Hanushek 2002) focuses both on differences in school quality and on other inputs including families, health, and abilities of a general form such as

2. There were some concerns about accuracy of the data series, leading to alternative developments (Cohen and Soto 2007) and to further refinements by Barro and Lee (2010), but the availability of this as a suitable measure of human capital has seemed clear over the past two decades. 
(2) human capital $=\beta_{1}$ schools $+\beta_{2}$ families $+\beta_{3}$ ability $+\beta_{4}$ health.

$$
+\beta_{5} \text { other factors }+v
$$

Unless families, health, and school quality are unrelated to school attainment, empirical growth modeling that simply substitutes school attainment for human capital in equation (1) will yield biased estimates of how human capital affects growth. Indeed, this observation is consistent with the early findings about the sensitivity of empirical growth models to model specification and the range of alternative factors considered (Levine and Renelt 1992).

An alternative approach is to measure human capital directly. Consistent with the educational production function literature and with the educational accountability movement, one can use standardized achievement tests of students as a direct measure of the relevant skills of individuals. This proves to be a very productive way to proceed in empirical growth models.

Cross-country skill differences can be constructed from international assessments of math and science (see the description in Hanushek and Woessmann [2011a]). These assessments, conducted over the past half century, provide a common metric for measuring cognitive skill differences across countries. ${ }^{3}$ This aggregate measure of a country's skills, labeled the knowledge capital in order to distinguish it from school attainment, provides for testing directly the fundamental role of human capital in growth, as found in equation (1). This approach to modeling growth as a function of international assessments of skill differences was introduced in Hanushek and Kimko (2000) and has been extended in Hanushek and Woessmann (2007, 2015a).

The fundamental idea is that skills as measured by achievement, $A$, can be used as a direct indicator of the knowledge capital of a country in equation (1) and, as described in equation (2), can be thought of as combining the skills of individuals from different sources in different countries. ${ }^{4}$

The impact of both school attainment and knowledge capital can be seen in the basic long-run growth models displayed in table 8.1. The table presents simple models of long-run growth over the period 1960-2000 for the set of fifty countries with required data on growth, school attainment, and achievement. Growth is measured by increases in real gross domestic product (GDP) per capita. The inclusion of initial income levels for countries is

3. Note that the various assessments over the past half century have not been designed to provide longitudinal information. It is possible to construct a longitudinal measure, however, by linking all international tests to US performance, which is independently measured over time with the National Assessment of Educational Progress (NAEP). See Hanushek and Woessmann (2015a).

4. Note, however, that the test scores at a given age or point in time are interpreted as an index of the skills of individuals. It is not the specifically tested information that is important, but instead the indication of relative learning levels that can be applied across the schooling spectrum. 
Alternative estimates of long-run growth models with knowledge capital

\begin{tabular}{lccc}
\hline & $(1)$ & $(2)$ & $(3)$ \\
\hline Cognitive skills (A) & & 2.015 & 1.980 \\
Years of schooling 1960 (S) & 0.369 & $(10.68)$ & $(9.12)$ \\
& $(3.23)$ & & 0.026 \\
GDP per capita 1960 & -0.379 & -0.287 & $-0.34)$ \\
& $(4.24)$ & $(9.15)$ & $(5.54)$ \\
No. of countries & 50 & 50 & 50 \\
$R^{2}$ (adj.) & 0.252 & 0.733 & 0.728 \\
\hline
\end{tabular}

Source: Hanushek and Woessmann (2015a).

Notes: Dependent variable: average annual growth rate in GDP per capita, 1960-2000. Regressions include a constant; $t$-statistics in parentheses.

quite standard in this literature, permitting the convergence of incomes. In simplest terms, it reflects the fact that countries starting behind can grow rapidly simply by copying the existing technologies in other countries while more advanced countries must develop new technologies (see Hanushek and Woessmann 2012).

The estimates in column (1), which mirror the most common historical approach, rely just on years of schooling to measure human capital and show a significant relationship between school attainment and growth. It explains one-quarter of the international variation in growth rates. Much of the existing empirical growth analysis was designed to go beyond this and to explain a portion of the remaining variation in growth, generally by adding additional measures of country differences including institutions, international trade, political stability, and the like.

The second column substitutes knowledge capital, the direct measure of skills derived from international math and science tests for school attainment, for years of schooling. Not only is there a significant relationship of knowledge capital with growth but also this simple model now explains three-quarters of the variance in growth rates. The final column includes both measures of human capital, that is, knowledge capital and school attainment. Importantly, once direct assessments of skills are included, years of school is not significantly related to growth, and the coefficient on school attainment is very close to zero.

These models, of course, do not say that schooling is worthless. They do say, however, that it is the portion of schooling directly related to skills that has a significant and consistent impact on cross-country differences in growth. The importance of skills and conversely the unimportance of just extending schooling that does not produce higher levels of skills has a direct bearing on human capital policies for both developed and developing countries. 
Two aspects of these estimates are relevant for policy consideration. First, it is the case that countries with higher skill levels also invest more in years of schooling. This holds for both developed and developing countries. Second, and very important for thinking about these results, education is a cumulative process, and later learning always builds on earlier learning. James Heckman and his colleagues describe it as dynamic complementarities, such that "skill begets skill" (Cunha et al. 2006; Cunha and Heckman 2007). The idea is very simple - schools not only build upon early learning, but the path of output follows a multiplicative function.

The estimated growth impacts of knowledge capital, scaled in standard deviations of achievement in table 8.1, are very large. The estimates imply that a one standard deviation difference in performance equates to 2 percent per year in average annual growth of GDP per capita.

Finally, estimating models in this form with a convergence term permits some assessment of the differences between the endogenous and neoclassical growth models, although full discussion is beyond this chapter. In the neoclassical model, the cumulative increases in GDP that emanate from increased human capital are approximately one-third less over a seventyfive-year period than those from the endogenous growth model, but they are still very substantial (see Hanushek and Woessmann 2011b). It remains difficult, however, to distinguish between the two models with existing data because insufficient data about changes in knowledge capital over time are available and because the impacts on growth are seen only in the distant future (see Holmes 2013).

A major concern with empirical growth modeling is that the estimated relationships do not measure causal influences but instead reflect reverse causation, omitted variables, cultural differences, and the like. This concern has been central to the interpretation of much of the prior work in empirical growth analysis, and indeed some have rejected the entire body of work on the basis of concerns about causation. Fully considering these issues goes beyond what can be presented here (see Hanushek and Woessmann 2012, 2015a), but it is possible to give some sense of the issues and their resolution.

An obvious issue is that countries that grow faster have added resources that can be invested in schools, implying that growth could cause higher scores. However, the lack of relationship across countries in the amount spent on schools and the observed test scores that has been generally found provides evidence against this (Hanushek and Woessmann 2011a). Moreover, a variety of sensitivity analyses show the stability of these results when the estimated models come from varying country and time samples, varying specific measures of cognitive skills, and alternative other factors that might affect growth (Hanushek and Woessmann 2012).

It is possible to address the main causation concerns with a series of alternative analyses, even if none of the tests is completely conclusive. To rule out simple reverse causation, Hanushek and Woessmann 2012 estimate 
the effect of scores on tests conducted until the early 1980s on economic growth in 1980-2000, finding an even larger effect of knowledge capital in the later period. Additional analysis considers the earnings of immigrants to the United States and cognitive skills in order to address the idea that cognitive skills are unimportant and that is just correlated with other causal factors. This analysis finds that the international test scores for their home country significantly explain US earnings, but only for those educated in their home country and not for those educated in the United States. This finding addresses simple issues of cultural differences because immigrants from the same country (but educated differently) are directly compared. By observing impacts within a single labor market, it also addresses possible concerns that countries with well-functioning economies also have good schools without the good schools driving growth.

Another analysis shows that changes in test scores over time are systematically related to changes in growth rates over time. In other words, it implicitly holds the country constant while looking at whether changing scores have the impact on changing growth rates that is predicted in table 8.1.

Finally, it is possible to exploit institutional features of school systems as instrumental variables for test performance. By employing only the variation in test outcomes emanating from country differences because of the use of central exams, decentralized decision-making, and privately operated schools, this instrumental variable approach both supports a causal interpretation and suggests that schooling can be a policy instrument contributing to economic outcomes.

While concerns about issues of causation still remain, the tests that have been done provide a prima facie case that improving cognitive skills and the knowledge capital of a country can be expected to improve economic growth. Each of the causation tests points to the plausibility of a causal interpretation of the basic models. But, even if the true causal impact of cognitive skills is less than suggested in table 8.1, the overall finding of the importance of such skills is unlikely to be overturned.

With this foundation of the relationship between knowledge capital and growth, it is possible to turn to issues affecting the distribution of income.

\subsection{Individual Earnings}

The overall distribution of income depends on a variety of factors including labor force participation, taxes, subsidies, international competition, firm ownership, and the like. Nonetheless, individual earnings will have a substantial influence on the ultimate distribution of income.

Importantly, cognitive skills of individuals have a clear and strong relationship to individual earnings and incomes. There has been a long history of investigating the determination of incomes and the role of human capital. While the relationship of skills to productivity of individuals dates back to 
Sir William Petty (Petty [1676] 1899) and Adam Smith (Smith [1776] 2010), the modern consideration of earnings determination is dominated by Jacob Mincer (Mincer 1970, 1974).

With a simple investment model, Mincer related school attainment (years of schooling) to individual earnings. Perhaps no other empirical relationship has had more influence than the Mincer earnings function. ${ }^{5}$ Over time this structure has been almost universally applied, and virtually any analysis considering individual variations in human capital measures skill differences primarily by years of schooling. Not only is there the conceptual support for this from Mincer's work and from subsequent developments, but also it was expedient because measures of years of schooling are ubiquitous in census and survey data. ${ }^{6}$

Unfortunately, characterizing the human capital of individuals simply by years of schooling ignores other elements of human capital determination and also eliminates most of the relevant policy deliberations about investments in human capital. As noted, there is extensive evidence from the educational production function literature that highlights the central role of families, peers, and neighborhoods - in addition to schools - on the achievement and skills of individuals (Hanushek 2002). As with growth modeling, this suggests that the typical estimates of the impact of human capital on earnings from a Mincer earnings function is actually the combined effect of added schooling and of the correlated influence of these other factors. Additionally, when any policy discussion turns to the influence of schools, the interest is more focused on issues of school quality than school quantity. While there is some discussion about school completion and about college access, most of the policy concerns are focused on aspects of school quality, something that is generally neglected in the analysis of individual earnings.

An alternative formulation that acknowledges these shortcomings in standard analyses of earnings determination is again to focus on individual measures of cognitive achievement as a direct measure of human capital. Such analysis has not been very common because of the general lack of measures of achievement or skills in surveys that have information about earnings and labor market activities. Recent data, however, are particularly apropos to understanding how skills relate to individual earnings.

The Programme for the International Assessment of Adult Competencies (PIAAC) provides labor market information and assessments of cognitive skills for a random sample of the population age sixteen to sixty-five in thirty-two separate countries (Organisation for Economic Co-operation and

5. The standard Mincer earnings function has log earnings as a linear function of years of schooling and a quadratic in potential experience (i.e., in years since completing schooling). It may then also include other specific factors influencing earnings.

6. To give an international view, Psacharopoulos and Patrinos (2004) estimated Mincer earnings functions for ninety-eight countries. 


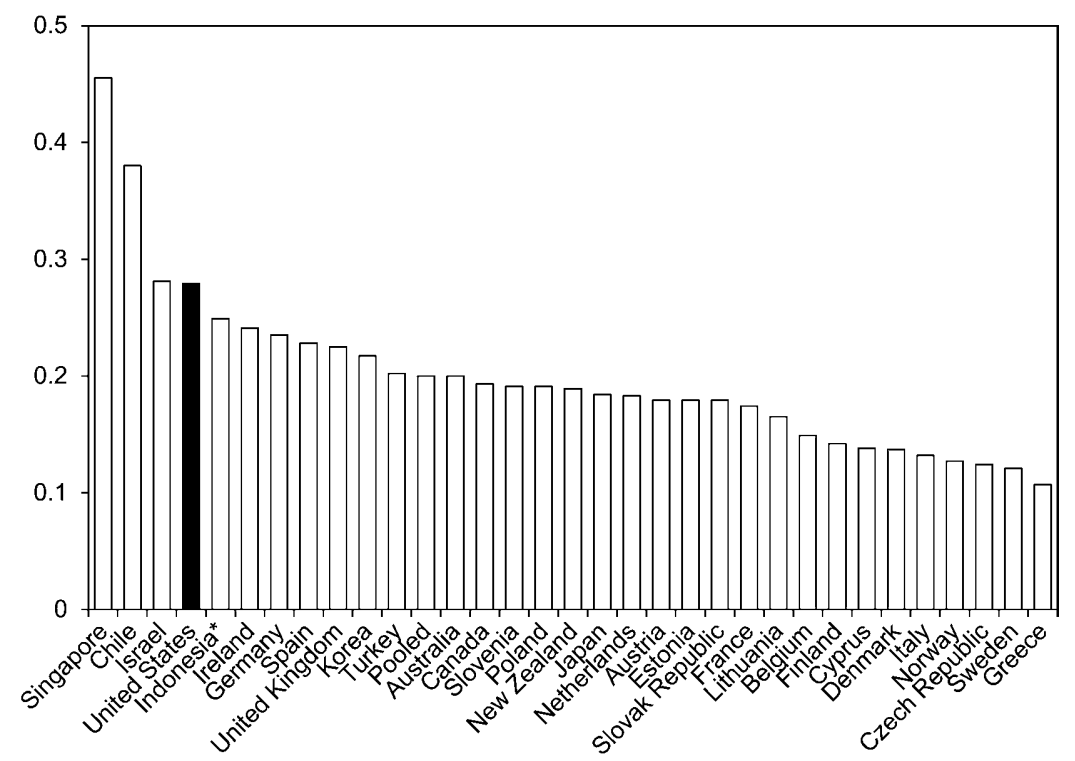

Fig. 8.1 Returns to numeracy skills

Source: Hanushek, Schwerdt, Wiederhold, and Woessmann (2017).

Note: Coefficient estimates on numeracy score (standardized to std. dev. 1 within each country) in a regression of log gross hourly wage on numeracy, gender, and a quadratic polynomial in age, sample of full-time employees age thirty-five to fifty-four.

*Jakarta only. Data source: PIAAC 2016.

Development [OECD] 2016). This survey of individuals collected demographic background along with labor market history. Sampled individuals also took tests in numeracy, literacy, and problem solving in technologyrich environments. These data are particularly useful for understanding the returns to skills. First, they provide information on earnings during mid- and later-life-cycle periods, when the value of skills becomes most observable. ${ }^{7}$ Second, by observing variations in returns across countries, it is possible to get suggestive insights into underlying causes of skill differences (Hanushek, Schwerdt, Wiederhold, and Woessmann 2017).

Estimates of the earnings-skills gradient, shown in figure 8.1, indicate that the United States has close to the highest return to skills across the thirtytwo countries. These estimates for numeracy skills indicate that a person one standard deviation above the mean numeracy score will, on average,

7. Most of the available evidence on returns to skills comes from US panel survey information where, unfortunately, the observations occur early in the work life. But early career returns provide underestimates of the full value of skills (Hanushek et al. 2015), perhaps because employers are still learning about individual skills (Altonji and Pierret 2001). 
earn 28 percent more per year throughout the working life. But this estimate also shows that low achievement is harshly dealt with by the labor marketbecause somebody at the 16th percentile of the achievement distribution (one standard deviation below the mean) will earn 28 percent below the average achieving worker.

These calculations underscore a basic fact: upgrading the skills of workers makes them more productive, which in turn raises their own incomes and improves overall growth of GDP. Pulling low achievers toward the mean implies lowering the variance in earnings while increasing the rate of growth of the economy - a point highlighted below.

There is, however, one additional aspect of the returns to individual skills that is relevant for consideration of growth-equity choices. Consistent with the arguments of Nelson and Phelps (1966), Welch (1970), and Schultz (1975), returns to skills appear to be higher when there is more economic change. Specifically, Hanushek, Schwerdt, Wiederhold, and Woessmann (2017) show that differences in returns to skills across countries are correlated with economic growth rates. In other words, growth and skills are complementary-higher skills imply greater growth that in turn implies greater returns to those higher skills.

\subsection{Illustrative Human Capital Policies and Growth-Equity Outcomes}

Most discussions of the human capital impact on both growth and distribution have looked exclusively at school attainment, and this has led to distortions of the policy discussions. Essentially discussions of alternative public policies have been inappropriately separated from the discussions of possible growth-equity trade-offs and growth-equity complementarities.

The evidence on growth and on individual earnings suggests that policies that improve learning while reducing the variance in achievement and skills will promote higher and more equitable incomes. Perhaps the most obvious program in this category involves preschool programs, although other ideas surrounding lifelong learning are also relevant.

\subsubsection{Early Childhood Education}

There is a broad consensus that the United States should expand its current preschool programs, particularly for disadvantaged students. From the demand side, there is little question that there are significant variations in the preparation of children for schooling and that these variations are systematically related to families' socioeconomic status. On the supply side, we have credible evidence that quality preschool can significantly improve achievement and life outcomes of disadvantaged students.

Evidence from a wide variety of sources indicates that disadvantaged students have less education in the home before entry into school. The Coleman Report, the massive governmental report mandated by the 1964 Civil Rights 
Act, first documented early achievement differences by family background (Coleman et al. 1966). These differences, documented in 1965, focused on racial differences. Another important investigation looked at the vocabulary of children and found dramatic differences by parents' socioeconomic status (Hart and Risley 1995). Both the amount and quality of parent-child interactions differed significantly, leading to large differences in vocabularies that directly reflected parental background. More recently, data from the Early Childhood Longitudinal Study documents the continuing early achievement deficits that accompany family background. Fryer and Levitt (2004) identify gaps in scores by socioeconomic status, while Reardon (2008) suggests that these gaps may have widened over many years.

How important are these initial gaps? Considerably so: while there is some disagreement about whether they shrink, expand, or hold constant over time in school, there is no evidence that they actually disappear. ${ }^{8}$

The final demand-side element for preschool is the significant impact on individuals' future incomes. The most direct relationship between early test performance and earnings is found in Chetty et al. (2011), which traces kindergarten performance directly to college completion and early career earnings. While recent public and media focus has largely concentrated on the top 1 percent of earners, such results point to the enormous implications of skill gaps within the remaining 99 percent of earners. ${ }^{9}$

The importance of early childhood learning in the overall growth-equity discussions is clear: the evidence suggests that high-quality programs tend to enhance the achievement of disadvantaged students - lifting the mean of the achievement distribution while lowering the variance. Thus, if effective, such programs both promote higher growth and more equity.

On the supply side, the existing evaluation literature generally suggests that preschool programs can be effective in raising achievement and other outcomes. Well-publicized studies with strong research designs, based on random assignment of students to programs, suggest high efficacy: the Perry Preschool Project, the Carolina Abecedarian Project, and the Early Training Project provide important evidence in favor of early childhood education (Schweinhart et al. 2005; Witte 2007). ${ }^{10}$ The experimental evidence has been supplemented by observational studies. Chicago's Child-Parent Center program (Reynolds et al. 2002), studies on preschool outcomes in Tulsa, Oklahoma (Gormley et al. 2005), and Georgia's universal pre-K program (Cascio and Schanzenbach 2013), generally indicate a positive impact for disadvantaged children (but no impact for more advantaged kids). Offsetting these results to some extent is the federal Head Start program, which

8. See, for example, the projections of racial gaps in achievement starting with those found in the Coleman Report (Hanushek 2016a).

9. See also the discussion in Autor (2014).

10. A comprehensive review of different pre-K programs and their evaluations can be found in Besharov et al. (2011). 
has been extensively evaluated and shows little success. ${ }^{11}$ One recent highquality evaluation, for instance, found that any achievement gains produced by Head Start disappear by third grade. Puma et al. (2012), the first randomassignment evaluation of Head Start, assessed a variety of child outcomes with none showing significant impact by third grade.

The caveat to this discussion is that little is currently known about the characteristics of effective preschool programs. The considerable discussion of various input requirements suggested for preschool programs has not been matched with evidence about the impact of different inputs. ${ }^{12}$ Understanding how to structure effective preschool programs and how to price and provide access to them are remaining questions that are central to developing actual policies.

\subsubsection{Lifelong Learning}

Changing the skill level of youth, while effective in improving both longrun growth and equity according to existing research, does take a long time to have its economic impact (Hanushek and Woessmann 2015a, 2015b). This suggests short- to middle-range economic effects that might be different. Specifically Autor (2014), in summarizing a number of studies, shows how the income distribution has widened in the United States in recent decades and relates this to differential skills. Specifically, more educated workers have been able to adjust to changed demands and have seen their earnings diverge from those of less educated. While the central focus is on differences in school attainment, it is almost certainly true for cognitive skills.

One aspect of this adaptation to change has been the ability of the more skilled to train for different job demands. As noted above, the ability to continually train and adapt is reflected by the higher returns to skills that accompany faster growth (Hanushek, Schwerdt, Wiederhold, and Woessmann 2017). This adjustment to change has led to continual calls for enhancing lifelong learning, particularly by those in jobs subject to more intense competition and by those currently receiving less continual training and upgrading.

If effective, enhanced lifelong learning would tend to make growth and equity more complementary because it is the lower skilled that generally receive less training throughout their career. Moreover, as discussed below, the need for improved career training has been emphasized for workers with vocational training, who generally have more specific skills that are more subject to lessened demand with changes in job demands. For this reason,

11. In practice, Head Start is not a unified program but rather a funding stream with loose regulations on the character of actual programs. As such, Head Start programs display considerable heterogeneity.

12. For discussion from the policy perspective, see Hanushek (2015). 
regular calls for support of lifelong learning are more common in the European Union with its more plentiful use of vocational training.

The problem from a policy viewpoint is that ideas about the appropriate policies to support lifelong learning generally fall short of the appeals for expansion. Little empirical knowledge exists about appropriate incentives to individuals or firms that would effectively expand lifelong learning. ${ }^{13}$

\subsubsection{Vocational Education}

Of course, not all education policies produce a long-run felicitous growthequity outcome. ${ }^{14}$ For example, there are many examples of ineffective policies that fail to yield improved student outcomes. This fact is easiest to see in both cross-country and within-country analyses of the inconsistent relationship between resources to schools and outcomes (see, e.g., Hanushek and Woessmann 2011a; Hanushek 2003). ${ }^{15}$ Little evidence suggests that just spending more on schools within the current institutional arrangements is likely to lead to much improvement.

More interestingly, there are educational programs that meet their declared goals but that might simultaneously suggest trade-offs between growth and equity. This includes intensive vocational education and programs that skew education toward the elite.

One major educational policy decision countries face is how much to emphasize vocational education, that is, education that is designed to produce more job-related skills, rather than the standard general education program. Vocational education programs, popular in both Europe and many developing countries, aim to ease the school-to-work transition of youth by directly providing skills that industries demand. Attention was particularly focused on these programs following the 2008 recession, in part due to the success of the German economy that is built on its apprenticeship program and intensive vocational education. And, while the United States has largely dismantled its vocational education program, there has been more recent attention to the possibility of reinstating at least part of the system (e.g., Lerman 2009).

Most of the attention has focused on the school-to-work transition. The evidence on the impact of vocational education on labor market entry is somewhat ambiguous because of the selectivity of choice across school

13. In closely related work, governments often have training programs for unemployed adults. These programs are sometimes effective, but it is hard to describe precisely when they are successful or what are the characteristics of successful programs (McCall, Smith, and Wunsch 2016).

14. Much discussion surrounding short-run growth and employment focuses on such things as labor and product market regulations, taxes, and subsidies. In the long run, however, these do not show any relationship with growth (Hanushek and Woessmann 2015a).

15. Strictly speaking, poor education programs may lower growth and widen the income distribution. 
types, but there is a general sense that vocational education does in fact make career entry easier (Ryan 2001). However, the impact of vocational education on the growth-equity relationship proves to be more complicated.

In the short run, expanding vocational education programs would, if they get youth into the labor market more quickly, tend to lead to expansion of the economy and to higher incomes at the lower end of the income distribution - a case of an education program that moves toward more growth and more equity.

The long run may, however, be different. Krueger and Kumar (2004) suggest that a significant contributor to the overall lower growth rates in Europe as opposed to the United States may be the reliance on vocational education, particularly in the face of labor market regulations that lead to market distortions. The idea is that firms choose lower-skill technologies when workers have more skill-based training as opposed to general training. The advantage of the United States is that broad general education and limited labor market regulation allows firms to seek better technologies.

From a different perspective, Hanushek, Schwerdt, Woessmann, and Zhang (2017) look at the life-cycle impacts of vocational versus general education. They test the simple hypothesis that individuals with vocational education are less able to adapt to changed technologies and thus their employment opportunities later in life are diminished. For countries with the most intensive vocational education - apprenticeship countries - there is a clear lessening of employment later in the life cycle when compared to those with general education. The lowered employment later in the life cycle is also found in other countries with less intensive vocational education programs, but the decline in employment is not as sharp.

Others have subsequently looked at the same hypothesis with somewhat varying results. Hampf and Woessmann (2017) confirm the major findings using more recent data across a larger number of countries. Forster, Bol, and van de Werfhorst (2016) find the same overall life-cycle pattern across countries but do not find the strong differences by intensity of the vocational system in different countries; they find the pattern to be consistent across a wide range of countries. For Britain, Brunello and Rocco (2017) find employment declines for those with vocational education, but the later declines do not appear to be large enough to offset the initial employment gains.

Taken together, the evidence suggests that movement toward expanded vocational education is unlikely to lead to more rapid long-run growth. Moreover, it does not appear to lead to more equitable outcomes, even if it has a short-run impact of improving the school-to-work transition. These issues are especially important in developing countries where the main focus is on increased growth. To the extent that a country experiences more rapid growth, the economy is going through larger changes - and this is just where individuals with vocational education tend to be at a larger disadvantage over time.

The existing evidence does not argue against all vocational education. The 
analysis in Hanushek, Schwerdt, Woessmann, and Zhang (2017) indicates that one of the elements of the improved life-cycle employment of those with general education is that they tend to get more ongoing education through their careers. Thus, programs that ensured continued education for those with vocational - that is, lifelong learning - could ameliorate the later life disadvantage of vocational education. But, as noted previously, the potential desirability of lifelong learning has not been matched by programs or institutions that have been very effective in its provision.

\subsubsection{Higher Education and Elite Programs}

Perhaps the most common educational policy initiative today is a call for expansion of college and university training. The growth models in table 8.1, however, indicate that once direct assessments of skills are included, school attainment is not significantly related to growth, and the coefficient on school attainment is very close to zero. These results hold even if the amount of tertiary education is separately considered (Hanushek 2016b).

These models, of course, do not say that schooling is worthless. They do say, however, that it is the portion of schooling directly related to skills that has a significant and consistent impact on cross-country differences in growth. The importance of skills and conversely the unimportance of just extending schooling that does not produce higher levels of skills has a direct bearing on human capital policies for both developed and developing countries. ${ }^{16}$

Of course, there are no scientists and engineers without higher education, so the insignificance for growth of having more college education appears strange. But, this can be interpreted as just a special case of the dynamic complementarities discussed previously (Cunha et al. 2006; Cunha and Heckman 2007). The idea is very simple - schools not only build upon early learning, but the path of output follows a multiplicative function. Students who enter college better prepared can be expected to learn more and be more productive on graduation, and this skill differential over less prepared students dominates any productivity effect of adding a greater number of less prepared graduates.

The one potential anomaly about tertiary education is that the growth models appear slightly different for just OECD countries. In the presence of knowledge capital, years of tertiary schooling has a positive effect (significant at the 10 percent level) for the twenty-four OECD countries in the sample (Hanushek 2016b). But this effect is entirely driven by the United States. If the United States is dropped, the estimated impact of higher education falls and is statistically insignificant.

16. Holmes (2013) also shows that neither the level nor the change in tertiary schooling for a larger group of countries is positively related to growth, even in the absence of knowledge capital measures. 
How should this apparent impact in the United States be considered? It turns out that the United States has grown faster than would be predicted by the basic growth models with knowledge capital (i.e., the United States has a positive residual in the regression models of table 8.1). The United States is generally regarded as having the best universities, and this quality may make the difference. But, perhaps more importantly, the United States has been able to attract highly skilled immigrants. The latter argument is quite consistent with the previous growth results, because the measure of achievement of US students would not capture the skills of the immigrants. Hanson and Slaughter (chapter 12, this volume) find that 55 percent of $\mathrm{PhD}$ workers in the United States in science, technology, engineering, and mathematics (STEM) fields were foreign born. In other words, the United States is able to bring in highly skilled individuals who frequently get $\mathrm{PhDs}$ at US universities and then remain to work in the United States. ${ }^{17}$ In short, it is difficult to attribute the faster-than-expected growth in the United States just to the impact of higher education for US students.

Even though expanding higher education may not have any clear impact on growth rates, it would be expected to add to income inequality. With increases in the labor market returns to higher education, past expansion of college education has led to increased income inequality, and, while not certain in the future, might be expected have similar impacts in the future (Autor 2014).

A slightly different perspective focuses on whether the education system favors providing basic skills or developing high performers. The previous growth models uniformly considered just country-average skills. Yet, particularly in developing countries, there is often a large variance in performance with some very high performers and many very low performers (see Hanushek and Woessmann 2008). These choices can, however, also be seen in developed countries, as with the US accountability system that has emphasized bringing all students up to a minimum achievement level.

In terms of modeling growth, it is possible to separate the impacts of the proportion of high performers and the proportion with basic literacy as assessed by the cognitive skills tests. Importantly, both broad basic skills ("education for all" in terms of achievement) and high achievers have a separate and statistically significant impact on long-term growth (Hanushek and Woessmann 2015a). These estimates, while suggestive, do not answer the overall policy question about where to invest resources. To address that question, it is necessary to know more about the relative costs of producing more basic and more high performers. In fact, no analysis is available to describe the costs of producing varying amounts of skills.

17. The United States has also had generally the strongest economic institutions for growthfree and open labor and capital markets, limited government regulation, secure property rights, and openness to trade. These institutions could further add to the explanation of the fasterthan-expected growth. 
At the same time, in terms of the interplay between growth and equity, investing relatively more in the top-end skills would clearly lead to a wider income distribution compared with investing at the bottom end. Thus, understanding whether growth and equity move together or not depends on the magnitude of potential changes in the distribution of achievement.

\subsection{Conclusions}

This chapter considers how recent analyses of the role of skills in long-run economic growth and in individual earnings changes significant parts of the discussion of possible growth-equity trade-offs. The key driver for individual incomes and for economic growth from this work is the cognitive skills of the individual - skills that are developed not only in schools, but also in the family and in neighborhoods. This perspective changes conclusions about policies considerably.

Human capital is always mentioned as part of both aggregate growth and individual incomes. But, if human capital is thought of just as it is commonly measured - by school attainment - the policy discussions become very distorted. Moreover, in discussions of the potential growth-equity trade-offs that frequently occur, the message of improved human capital can be quite misunderstood.

The common policy discussion in education is largely around the quality of schools. That, in fact, is the correct focus because the skills that are important for growth and for individual incomes involve achievement and learning as opposed to just years spent in school.

While the distribution of income involves many factors, a key element is the distribution of earnings. In that regard, many policies that improve school quality will lead to growth-equity complementarities.

\section{References}

Altonji, Joseph G., and Charles R. Pierret. 2001. "Employer Learning and Statistical Discrimination." Quarterly Journal of Economics 116 (1): 313-50.

Autor, David H. 2014. "Skills, Education, and the Rise of Earnings Inequality among the 'Other 99 Percent."' Science 344 (843): 843-51.

Barro, Robert J., and Jong-Wha Lee. 1993. "International Comparisons of Educational Attainment." Journal of Monetary Economics 32 (3): 363-94.

2010. "A New Data Set of Educational Attainment in the World, 19502010.” NBER Working Paper no. 15902, Cambridge, MA.

Benhabib, Jess, and Mark M. Spiegel. 1994. "The Role of Human Capital in Economic Development: Evidence from Aggregate Cross-Country Data." Journal of Monetary Economics 34 (2): 143-74.

Besharov, Douglas J., Peter Germanis, Caeli Higney, and Douglas M. Call. 2011. Assessing the Evaluations of Twenty-Six Early Childhood Programs. College Park, 
MD: Welfare Reform Academy, University of Maryland, July. http://www.welfare academy.org/pubs/early_education/index.shtml.

Brueckner, Markus, Era Dabla Norris, and Mark Gradstein. 2015. "National Income and Its Distribution." Journal of Economic Growth 20 (2): 149-75.

Brunello, Giorgio, and Lorenzo Rocco. 2017. "The Labor Market Effects of Academic and Vocational Education over the Life Cycle: Evidence from Two British Cohorts." Journal of Human Capital 11 (1): 106-66.

Cascio, Elizabeth U., and Diane W. Schanzenbach. 2013. "The Impacts of Expanding Access to High-Quality Preschool Education.” Brookings Papers on Economic Activity Fall: 127-78.

Castelló-Climent, Amparo, and Rafael Doménech. 2008. "Human Capital Inequality, Life Expectancy and Economic Growth.” Economic Journal 118 (528): 653-77.

2014. "Human Capital and Income Inequality: Some Facts and Some Puzzles.” BBVA Research Working Paper no. 12/ 28, Madrid, Banco Bilbao Vizcaya Argentaria. March.

Chetty, Raj, John N. Friedman, Nathaniel Hilger, Emmanuel Saez, Diane Whitmore Schanzenbach, and Danny Yagan. 2011. "How Does Your Kindergarten Classroom Affect Your Earnings? Evidence from Project STAR.” Quarterly Journal of Economics 126 (4): 1593-660.

Cohen, Daniel, and Marcelo Soto. 2007. "Growth and Human Capital: Good Data, Good Results.” Journal of Economic Growth 12 (1): 51-76.

Coleman, James S., Ernest Q. Campbell, Carol J. Hobson, James McPartland, Alexander M. Mood, Frederic D. Weinfeld, and Robert L. York. 1966. Equality of Educational Opportunity. Washington, DC: US Government Printing Office.

Cunha, Flavio, and James J. Heckman. 2007. "The Technology of Skill Formation." American Economic Review 97 (2): 31-47.

Cunha, Flavio, James J. Heckman, Lance Lochner, and Dimitriy V. Masterov. 2006. "Interpreting the Evidence on Life Cycle Skill Formation." In Handbook of the Economics of Education, vol. 1, edited by Eric A. Hanushek and Finis Welch, 697-812. Amsterdam: North Holland.

Forster, Andrea G., Thijs Bol, and Herman G. van de Werfhorst. 2016. "Vocational Education and Employment over the Life Cycle." Sociological Science 3:473-94.

Fryer, Roland G., Jr., and Steven D. Levitt. 2004. "Understanding the Black-White Test Score Gap in the First Two Years of School." Review of Economics and Statistics 86 (2): 447-64.

Galor, Oded. 2011. "Inequality, Human Capital Formation, and the Process of Development." In Handbook of the Economics of Education, vol. 4, edited by Eric A. Hanushek, Stephen Machin, and Ludger Woessmann, 441-93. Amsterdam: North Holland.

Gormley, Jr., William T., Ted Gayer, Deborah Phillips, and Brittany Dawson. 2005. "The Effects of Universal Pre-K on Cognitive Development." Developmental Psychology 41 (6): 872-84.

Hampf, Franziska, and Ludger Woessmann. 2017. "Vocational vs. General Education and Employment over the Life-Cycle: New Evidence from PIAAC." CESifo Economic Studies 63 (3): 255-69.

Hanushek, Eric A. 2002. "Publicly Provided Education." In Handbook of Public Economics, vol. 4, edited by Alan J. Auerbach and Martin Feldstein, 2045-141. Amsterdam: North Holland.

. 2003. "The Failure of Input-Based Schooling Policies." Economic Journal 113 (485): F64-98.

- 2015. "The Preschool Debate: Translating Research into Policy.” In The Next 
Urban Renaissance: How Public-Policy Innovation and Evaluation Can Improve Life in America's Cities, edited by Ingrid Gould Ellen, Edward L. Glaeser, Eric A. Hanushek, Matthew E. Kahn, and Aaron M. Renn, 25-40. New York: Manhattan Institute for Policy Research.

2016a. "What Matters for Achievement: Updating Coleman on the Influence of Families and Schools." Education Next 16 (2): 22-30.

2016b. "Will More Higher Education Improve Economic Growth?" Oxford Review of Economic Policy 32 (4): 538-52.

Hanushek, Eric A., and Dennis D. Kimko. 2000. "Schooling, Labor Force Quality, and the Growth of Nations." American Economic Review 90 (5): 1184-208.

Hanushek, Eric A., Guido Schwerdt, Simon Wiederhold, and Ludger Woessmann. 2015. "Returns to Skills around the World: Evidence from PIAAC." European Economic Review 73:103-30.

- 2017. "Coping with Change: International Differences in the Returns to Skills." Economic Letters 153 (April): 15-19.

Hanushek, Eric A., Guido Schwerdt, Ludger Woessmann, and Lei Zhang. 2017. "General Education, Vocational Education, and Labor-Market Outcomes over the Life-Cycle." Journal of Human Resources 52 (1): 48-87.

Hanushek, Eric A., and Ludger Woessmann. 2007. Education Quality and Economic Growth. Washington, DC: World Bank.

- 2008. "The Role of Cognitive Skills in Economic Development." Journal of Economic Literature 46 (3): 607-68.

2011a. "The Economics of International Differences in Educational Achievement." In Handbook of the Economics of Education, vol. 3, edited by Eric A. Hanushek, Stephen Machin, and Ludger Woessmann, 89-200. Amsterdam: North Holland.

. 2011b. "How Much Do Educational Outcomes Matter in OECD Countries?" Economic Policy 26 (67): 427-91.

2012. "Do Better Schools Lead to More Growth? Cognitive Skills, Economic Outcomes, and Causation." Journal of Economic Growth 17 (4): 267-321.

. 2015a. The Knowledge Capital of Nations: Education and the Economics of Growth. Cambridge, MA: MIT Press.

-2015b. Universal Basic Skills: What Countries Stand to Gain. Paris: Organisation for Economic Co-operation and Development.

Hart, Betty, and Todd R. Risley. 1995. Meaningful Differences in the Everyday Experience of Young American Children. Baltimore: Paul H. Brookes Publishing Co.

Holmes, Craig. 2013. "Has the Expansion of Higher Education Led to Greater Economic Growth?” National Institute Economic Review 224 (1): R29-47.

Krueger, Dirk, and Krishna B. Kumar. 2004. "Skill-Specific Rather Than General Education: A Reason for US-Europe Growth Differences?" Journal of Economic Growth 9 (2): 167-207.

Kuznets, Simon. 1955. "Economic Growth and Income Inequality." American Economic Review 45 (1): 1-28.

Lerman, Robert I. 2009. Training Tomorrow's Workforce: Community College and Apprenticeship as Collaborative Routes to Rewarding Careers. Washington, DC: Center for American Progress, December.

Levine, Ross, and David Renelt. 1992. "A Sensitivity Analysis of Cross-Country Growth Regressions." American Economic Review 82 (4): 942-63.

Lucas, Robert E., Jr. 1988. "On the Mechanics of Economic Development." Journal of Monetary Economics 22 (1): 3-42.

Mankiw, N. Gregory, David Romer, and David Weil. 1992. "A Contribution to the Empirics of Economic Growth.” Quarterly Journal of Economics 107 (2): 407-37. 
McCall, Brian, Jeffrey Smith, and Conny Wunsch. 2016. "Government-Sponsored Vocational Education for Adults." In Handbook of the Economics of Education, edited by Eric A. Hanushek, Stephen Machin, and Ludger Woessmann, 479-652. Amsterdam: Elsevier.

Mincer, Jacob. 1970. "The Distribution of Labor Incomes: A Survey with Special Reference to the Human Capital Approach." Journal of Economic Literature 8 (1): $1-26$.

. 1974. Schooling, Experience, and Earnings. New York: National Bureau of Economic Research.

Nelson, Richard R., and Edmund Phelps. 1966. "Investment in Humans, Technology Diffusion and Economic Growth.” American Economic Review 56 (2): 69-75.

Organisation for Economic Co-operation and Development (OECD). 2016. Skills Matter: Further Results from the Survey of Adult Skills. Paris: OECD.

Ostry, Jonathan D., Andrew Berg, and Charalambos G. Tsangarides. 2014. "Redistribution, Inequality, and Growth.” IMF Staff Discussion Note no. SDN/14/02, Washington, DC, International Monetary Fund, February.

Petty, Sir William. (1676) 1899. "Political Arithmetic." In The Economic Writings of Sir William Petty, edited by Charles Henry Hull, 233-313. Cambridge: Cambridge University Press.

Psacharopoulos, George, and Harry A. Patrinos. 2004. "Returns to Investment in Education: A Further Update.” Education Economics 12 (2): 111-34.

Puma, Michael, Stephen Bell, Ronna Cook, Camilla Heid, Pam Broene, Frank Jenkins, Andrew Mashburn, and Jason Downer. 2012. Third Grade Follow-Up to the Head Start Impact Study Final Report. Washington, DC: Office of Planning, Research and Evaluation, Administration for Children and Families, US Department of Health and Human Services.

Reardon, Sean F. 2008. "Differential Growth in the Black-White Achievement Gap during Elementary School among Initially High- and Low-Scoring Students." IREPP Working Paper no. 2008-07, Institute for Research on Education Policy and Practice, Stanford University, March.

Reynolds, Arthur J., Judy A. Temple, Dylan L. Robertson, and Emily A. Mann. 2002. "Age 21 Cost-Benefit Analysis of the Title I Chicago Child-Parent Centers." Educational Evaluation and Policy Analysis 24 (4): 267-303.

Romer, Paul. 1990. "Endogenous Technological Change." Journal of Political Economy 99 (5, pt. 2): S71-102.

Ryan, Paul. 2001. "The School-to-Work Transition: A Cross-National Perspective." Journal of Economic Literature 39 (1): 34-92.

Schultz, Theodore W. 1975. "The Value of the Ability to Deal with Disequilibria." Journal of Economic Literature 13 (3): 827-46.

Schweinhart, Lawrence J., Jeanne Montie, Zongping Xiang, W. Steven Barnett, Clive R. Belfield, and Milagros Nores. 2005. Lifetime Effects: The High/Scope Perry Preschool Study through Age 40. Ypsilanti, MI: High/Scope Press.

Smith, Adam. (1776) 2010. The Wealth of Nations. Hollywood, FL: Simon and Brown.

Welch, Finis. 1970. "Education in Production.” Journal of Political Economy 78 (1): $35-59$.

Witte, John F. 2007. "A Proposal for State, Income-Targeted, Preschool Vouchers." Peabody Journal of Education 82 (4): 617-44. 